Covered in: ERIH PLUS, CEEOL, Index Copernicus, CrossRef, CrossCheck, J-Gate, Google Scholar, Ideas RePeC, Econpapers, Socionet, KVK, WorldCat.

2020, Volume 8, Issue 2, pages: 01-16 | doi: 10.18662/lumenphs/8.2/41

\section{The Evolution of Mind and Reflexive Thinking Starting from the Ancient Greeks to Stoic Philosophers}

\section{Diana Laura CIUBOTARU1}

${ }^{1}$ Main psychologist, PhD Student, Alexandru Ioan Cuza University of Iasi, Romania, dl ciubotaru@yahoo.com
Abstract: The aim of this article is to investigate the vision of self-knowledge and the human ability to know oneself and also in relation to the source, starting from the ancient Greeks and exploring their sources of inspiration. Everything is pursued in relation to the affirmation: Man's selfconsciousness is a mirror of the source Consciousness, which knows itself through people. There are a few arguments in relation to this:

1. Self-awareness as a self-concern reflected in the universe, appears in pre-Socratic thinkers and outlined in Plato in the triadic vision, and much later is the subject of well-defined study in psychology. Therefore, a good knowledge of the subject starts from the first mentions.

2. The perspective of Stoic philosophers in which selfconcern is organized in the form of a set of clearly defined rules, well-defined procedures, a true process of transformation that is completed with the creation of an attitude of alignment Man-Universe / Universal Nature. It is the best represented system of self-conscious work of all the schools of philosophy up to that time.

Keywords: evolution; mind; reflexive thinking; philosophy.

How to cite: Ciubotaru, D.L. (2020). The Evolution of Mind and Reflexive Thinking Starting from the Ancient Greeks to Stoic Philosophers. Logos Universality Mentality Education Novelty: Philosophy \& Humanistic Sciences, 8(2), 01-16. doi: https://doi.org/10.18662/lumenphs/8.2/41 


\section{Introduction}

In order for man to experience consciousness, he needs a set of tools: the mind or reason, the thinking that processes the information coming from the internal and external environment. Then everything is organized in a vision of the world and about the source of the world. Here are some ideas developing from this statement:

1. If the Source cannot be known directly but through its mirrors, then how can man be known?

2. Man's self-consciousness becomes a mirror of self-knowledge. Through his questions and bending over the Self, man becomes aware of his power of knowledge, of action, of his will.

3. Man has the freedom to interpret himself and to discover in himself / another, because the source did not impose any predefined path.

4. The source is not static - it always becomes as we humans become and expand our minds and faculties of knowledge.

5. The mind is an aspect of human nature that allows the knowledge, by reflection of the source (Copleston, 2008):

- It could activate knowledge from other lives.

- He could access knowledge through revelation (he has not known it before, nor through other lives).

- He could access knowledge through faith in the truth and then experiment.

- He could access knowledge through a predetermined and mechanistic life.

\section{Knowledge and conscience. The Presocratics}

When was self-awareness in man born? We can speak of a slow growth of the mind, from the beginnings of humanity, as a species, to the present. The first act of reflection on oneself to record, were discovered through the drawings they left in caves older than our thoughts ... People saw themselves and left their minds inherited from their descendants through drawings, through tools, rituals and slowly, slowly over thousands of years through culture and technology.

The word consciousness derives from Latin and has its roots in conscio that was formed from its union of cum means "with" and scio what means "to know". Thus, etymologically speaking, consciousness means "to know with". In its original sense, being aware of something meant sharing that knowledge with someone or yourself (Zeman, 2001). All meanings - 
knowledge shared with oneself, with others or simply knowledge, have entered language under the umbrella of consciousness, the first equivalent of the term conscientia (Zeman, 2001). Through consciousness, one can know the external world or the inner world (Frunză, 2016), one's own mental states.

Adam Zeeman draws our attention to three main meanings that have dominated the definition of consciousness: "In a first variant, consciousness is defined as a state of awakening. The imprint of neurology can be seen here. Consciousness is equated with the ability to perceive, interact, and exchange information with the environment and others in a way that directly involves the state of being awake. In this sense we can distinguish between degrees of consciousness ranging from waking to comatose states, degrees that can be objectively evaluated with standardized tools. The second meaning of consciousness is as experience or phenomenological content of experience. This may include what you feel as a person, or what it is like to be in a certain way or something. This emphasizes the subjective or qualitative dimension of the experience. In the third situation, consciousness is seen as a mental state - any mental state with a propositional content can be considered conscious - which we believe, we hope, why we are afraid or our expectations. Consciousness was equated with the mind. It is found that most research has focused on the first two meanings rather than the last category" (Zeman, 2000).

If we look at it as an observer of a timeline from antiquity to the present, self-awareness is not clearly defined as a subject of discussion or as an object of study in ancient philosophy. Why would we go so far as to map a term that best fits its place in contemporary approaches to the philosophy of mind (and perhaps here, too, great debates continue about the explicitness and nature of consciousness)? Perhaps, because it is important to recognize man's effort to understand his own nature and to understand the nature of the world of which he is a part. This effort, put in the right angle, can be enlightening for the present discussions on the nature of consciousness, creates a foundation and a common language for modern disciplines (philosophy of mind, psychology, neuropsychology, cognitive sciences, psychophysics and others) that are curiously interested on this aspect which remains mysterious, up to a certain point, even today.

The first explicit records of self-awareness appear in historically

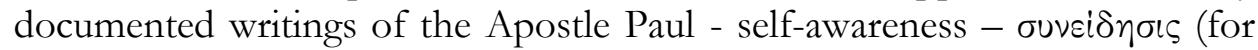
stoics), a term also used by Apostle Paul in his epistles (2 Cor. 1, 12; 4, 2; 5, 11 et passim) (Bosman, 2003). It is inspired by the writings of the Stoics, and they emerge from the foundations laid by Plato in his triadic vision, a vision 
that is influenced by pre-Socratic thinking. "Today, our entire culture - from physicists like Werner Heisenberg to some of the most representative poets of the time - invokes the verb and pre-Socratic thinking. Why? Perhaps it is an basic thought; or perhaps it encourages the meditative man to fundamental themes and attitudes, or opens the angles of attack essential to the impetus of knowledge. Or who knows? Maybe because it is, with the pre-Socratics, about what has been and remains stable, about what is (Diels, \& Kranz, 1974).

The people of antiquity were initially caught in a world they could only master in certain respects, a world they did not understand but were curious to know and justify. Their preoccupations with knowledge concerned the external world as nature, the Universe as well as the relational world, as human systems in which they sought their place and meaning. Those who persevered in these preoccupations went even deeper to the last stronghold, the self. Inevitably, the big questions arise: And who made all this, for whom was it made, and by whom was I made? The evolution of research thus goes from the glimpse of the self as an indirect subject of discussion and as an unclear object outlined by study, to its clear definition today, as an object of scientific study in psychology, and shaping as an always fertile subject of discussion, in the contemporary period, especially with the newly emerged self-definition and self-awareness in the area of study of Artificial Intelligence.

What we are approaching now as a thesis is not what we can know, but the moments when people realized that they have a self that can know, a self that can be defined, refined, processed, transformed, put into a relation to something greater, possibly the attempt to define something greater through the prism of the self and vice versa. The self as an outsourced object, the self as a connoisseur of the world and what is its relationship with its creator or its source. Our assumption is that the source mirrors itself in the knowing self, so we can assume a circular relation of evolution, from the knowing self to the source, which expands and mirrors itself again in the human knowing self. This circular relationship can be considered, or defined, both at the human level in a single individual life cycle and at the collective level in successive and evolving information cycles or waves, as defined, for example, by Alvin Toffler in The Third Wave, or Mihai Draganescu in the Society of Consciousness.

As Frederick Copleston tells us: "The Greeks are, without a doubt, the first thinkers and scientists in Europe. They were the first to seek knowledge for the sake of knowledge, and they pursued knowledge in a scientific, free and impartial spirit." (Copleston, 2008). This is an argument 
in their tireless pursuits of the nature of reality, the nature of the mind, its ability to know the world, and ultimately its creator. This allowed the continuous processing and refinement of theories until the construction of robust systems that could answer the questions asked. Man is placed systemically in relation to other elements with which he is interrelated, and power becomes a concept with a special reality in the minds of Greek thinkers: the power of the gods over men, the power of man over reality, over other people and last but not least, over the self, the mind of the body and its nature.

We will look at the birth of self-awareness as an act of slow maturation of the mind or the knowing self. In fact, without a constant questioning action on the world, the mind cannot come to question its own nature. Analysing the writings of the ancients, a model emerges, quite timid at first, of the knowing self that looks at the source with wonder and curiosity. At first it was seen as something separate from the knowing self, and the self-experienced the anguish of lack of protection and the confused loneliness of unanswered aspiration, the pressure of a power at its mercy, feelings reflected in the philosophical and literary writings of that time, in their mythological creations and religious concerns.

Its folding inwards, in the act of self-reflection, shows, in fact, its moment of transformation, and of the search for the source inwards in the desire for fulfilment and meaning. Thus, her questions put her in a new position of knowledge, in which she is no longer separated from the source. Of course, this position also brings new challenges, including the difficulty of observing oneself and the containing source, simultaneously. It's like asking a fish if he knows what water is, given that he can't live outside of it. The oscillation of the knowing self was thus between knowing the source as permanence, observing it in a static and eternal Now, and knowing the source in all that it becomes. The difficulty of the knowing self to capture the source in everything that manifests in the universe required many cumulative life cycles and the repeated systematization of knowledge obtained in systems, or refined doctrines over hundreds of years. We can even say thousands of years, if we consider the latest theories on the nature of consciousness, which states that the universe can be self-aware, not only by simply accumulating the consciousness of knowing subjects, but by the emergence of collective field properties of consciousness, or information field (Drăgănescu, 2000).

F. Copleston also helps us to see a history of the development of the themes of reflection on the source: "These thinkers saw that, despite all the changes and transitions, there must be something permanent. Why? Because 
change happens from one thing to another. There must be something primordial, which persists, which takes various forms and goes through this process of change. Change cannot be just a conflict of opposites; the thinkers were convinced that there was something behind these opposites, something paramount." (Copleston, 2008, p.18).

During this period, the search for the primordial element is an obvious concern and the first attempts to explain the nature of reality appear, thinkers resorting to particular elements of nature, elements that satisfy both the criterion of unity, becoming and transformation. All their effort is a reflection of the freshness of their minds at that time, a reflection of the point at which knowledge had reached. We could say that we are in the childhood stage of science, the foundations are laid for the future scientific thinking, for a thinking that wants to explain and justify the reality and the material world. Although they hit the limits of the senses, they explored solutions through speculative thinking: "In order to reach the conception of anyone as the ultimate element of all things, it is necessary to go beyond appearance and senses. And they did not reach their conclusions through a scientific, experimental approach but through the speculation of speculative reason: the postulated unity is indeed a material unity, but it is a postulated unity of thought." (Copleston, 2008, p.18). The author's emphasis on the Greeks' trust in a universal law is also very useful, a concept that takes the ground of reality out of the capricious world of mythology and places us in the area of a future scientific cosmology. We do not yet have clear theories about self-knowledge, we do not explicitly address selfawareness, but we can see how the knowing subject prepares, by seeking permanence in the universe, future questions about the permanence of his mind, and how the mind can be transferred to future through knowledge.

The search for this unifying element shows the maturation of thought and its return without fear, or at least with tolerable anxiety, to what was considered intangible or as belonging to the gods, because only they could explain the nature of the world and reality, consequently only they could control it. Early Ionian philosophers outline before our eyes a philosophical thought combined with a pragmatic thinking -Thales expounding a doctrine in which things are conceived as variations of a primordial element and strives to find unity in diversity. Anaximander, the successor of Thales" has two reasons for praise: he is the first philosopher to write down his ideas and, at the same time, the first to draw a map of the world ... he rejected the mythological explanations of events in favour of naturalistic and logical ones" (Pirie, 2011, pp. 9-10). He takes the idea of unity and introduces the concept of Indeterminate Infinity from which all 
things come looking for possible explanations for how the world developed from it.

It is worth mentioning here, Anaxagoras for appealing to the concept of nous, mind, as the driving force of the universe viewed systemically, as more than the sum of its parts. We are interested in his perspective even more, as he was convinced that "the meaning of life is the research of the universe" (Pirie, 2011, p. 1).

In our exploration, these first consistent reflective mentions of minds that systematically analyze the outside world lay the foundations of self-knowledge as part of the universe they are trying to understand beyond the fears of magic and religion-driven thinking.

Copleston concludes that: "The central significance of Ionian thinking lies in the fact that they raised the issue of the ultimate nature of things, and less in the answers they each gave to that issue. At the same time, we can point out that all have assumed the eternal character of matter: the idea of an absolute beginning of this material world did not come to them. Indeed, for them, this world is the only world." (Copleston, 2008, p.26).

If we go along the timeline of the thought development, we can stop at the Pythagoreans, or rather the Pythagorean society, in the years 500 BC where it draws our attention to the fact that they are already creating a set of instructions for a lifestyle associated with the cultivation of thought. The mind is not only oriented outwards, towards understanding and knowing the world but returns with questions to itself, in the idea of purifying the soul (the doctrine of soul transmigration generating a series of ascetic-religious practices, supporting the education of the soul, for example the practice of silence, influence music, the study of mathematics). "The religious renaissance had brought back to life the idea of the power of the soul and its continuing vigour after death - in contrast to the Homeric conception of the clumsy shadows of the departed. In a doctrine such as the transmigration of souls, the consciousness of personal identity, self-consciousness, is not present in the mind nor considered as related to the soul, as Dr. Julius Stenzel says:"...die Seele wandert von Ichzustand zu Ichzustand, oder, was dasselbe ist, von Leib zu Leib; denn die Einsicht, dass zum Ich der Leib gehort, war dem philosophischen Instinkt der Griechen immer selbstverständlich." [... the soul migrates from one state of the self to another, which is the same thing, from one body to another; so the intuition that the body is part of the ego has, of course, always been the philosophical instinct of the Greeks] (Copleston, 2008, p.29). 
The Pythagoreans pay great attention to the soul, being the most important part of man, perhaps even his real part, and this idea that differentiates them from materialists will later influence Plato: "The Pythagoreans were certainly impressed by the importance of who has the soul and the right care of it, and this was one of the most beloved beliefs of Plato, to whom he held all his life. Plato was also influenced by the mathematical speculations of the Pythagoreans - even if it is difficult to determine to what extent he is indebted to them in this regard." (Copleston, 2008, p.34).

Following the historical thread exposed by Copleston, we can see how Greek thought has reached the stage where it tries to explain the OneMultiple relationship, an important moment, moreover, for the argumentation of our statement. The 6th and 5th century BC is marked by the existence of the seven sages: "The historical existence of the seven sages even if the authenticity of the maxims attributed to them is uncertain seems to have been real. They would have lived in the first half of the sixth century, and although they were distinguished by their way of life and concerns, they ended up becoming statesmen and legislators. Indeed, the political and social role entrusted to them could allow, in this respect, a rapprochement between people whom nothing else could have united: a Thales, for example, adds to his biography of a philosopher, astronomer, mathematician or engineer also the position of statesman." (Diels, \& Kranz, 1974, p.101).

In those moments of economic and social up and downs, the role of knowledge was essential in redefining the values of Ancient Greece. The exhortations and maxims of the sages of the ancient world will later bear fruit in consistent writings and perennial systems of thought.

\section{The logos of Heraclitus}

The essence for this Greek thinker from the 500s BC, is fire (a notion later taken over by the Stoics). What makes it different from its predecessors is that it sees the One existing in the multiple, and the Identity in the Difference (Copleston, 2008, p.37). He integrates the opposites and their struggle, seeing the tension between them essential and normal for the One, although it is not understood by ordinary minds. According to an external observer who would have enough time available like the gods, one could perceive the invisible harmony of the universe, the balance between the upper path and the lower path. In One the tensions are reconciled and everything is fine as it is, without polarity (Banu, 1979, p.357). 
One is wise, he is Divine (Banu, 1979, p.355): "Divinity is the universal Reason, the universal law immanent to all things which unites all things in one unity and determines the permanent change in the universe in accordance with the universal law. Human reason is a moment of universal Reason, or a contraction or channeling of it." (Copleston, 2008, p.39).

These indications of how the mind works, "being satisfied... and without revolting" (Copleston, 2008, p.39) making a master plan of the unity of all things, would result in keeping the soul as dry as possible: "The dry soul is the one wiser and better" (Banu, 1979, p.365). This form of the soul is valued, in opposition to the wet soul, more pleasant, tempting, but leading to death. "Souls should strive to rise above the private world of sleep and reach the common world of awakening, that is, the world common ground of thought and reason ... by emphasizing universal law and man's participation in Reason, Heraclitus thus prepared the ground for the universalist ideals of the Stoics." (Copleston, 2008, p.40).

Heraclitus' pantheism was taken up by the Stoics in the form of an all-powerful Universal Reason. The intellect, through the position of nonjudicial observer, tries to conceive a systemic unity, regarding the elements parties in an interdependent relationship. Man as a system: his body, his soul, his psychic and mental life, his cultural life. It all depends on the interaction with the environment, the past or the history of the environment-system in which he was born, as a material and cultural universe.

The solution given by Heraclitus, the permanent transformation, allows systems to evolve without losing their essence, One. We can say that it is a law applicable in physics until now (the law of conservation of energy and the principles of systemic thinking).

\section{Plato - the triadic vision of the soul}

Plato is inspired by the Pythagoreans to develop his doctrine. In the dialogue The Republic (Platon, 1986b) resembles the soul with a fortress: "The soul consists of "three parts", the "rational" part, the "brave or animated part" and the sensual" appetitive part" (Copleston, 2008, p.188). These parts are considered immaterial, being rather forms of action. The first part, rational, is divine in nature, the others being perishable and mortal. The immortal soul retains its memory after death, being influenced by lifestyle and decisions made during life. Copleston (2008, p.188) asks this question, why Plato supported this tripartite vision of the soul, the answer being related to the internal conflict staged by the famous comparison in the 
Phaidros dialogue, "in which the rational element is like a coachman, and the active and appetitive part compared with two horses. One horse is good (the active element, which is the natural ally of reason and loves honor with restraint and modesty), the other is bad (the appetitive element, which is the friend of all revolts and shamelessness)" (Copleston, 2008, p.189).

Thus, a good self-knowledge would be the understanding of instincts and their restraint, at the same time as the cultivation of a rational attitude. Plato thus elaborates a first topic, including the human psyche. The lively, courageous part, by creating an alliance with the immortal part, by which it is guided, could well control the sensual passion. Plato also refers to localizations in the human body of these courts, in the dialogue of Timaios, "the rational part of the soul being located in the head, the animated part in the chest, and the appetitive part under the diaphragm" (Copleston, 2008, p.189).

Having these different sources of action within us raises the logical question of harmonizing and resolving the conflict between them. As Socrates says in Phaidros: "We must remember that in each of us there are two principles that guide and master us and that we follow wherever we go; one is planted in us from birth, namely the desire for pleasures; the other is an acquired trust, namely the thought that we must strive for the best. These two principles that dwell in us, now live in harmony, are now they are arguing; one after another. And when a well-thought-out judgment is the one that leads us to good and wins, we call this victory, temperance" (Platon, 1986a, p.431). Life is a journey in truth and all three principles are put in the service of good. The construction of the mind and personality, the refinement of character, is done through hard work, respecting a personal and societal life textbook, the result being not only a life lived in harmony but also a life after death with value and meaning.

Who did the rational and immortal part? Plato speaks of the creative Demiurge, who made this part of the soul of the world: "an object that moves another, and that is moved by another, can cease to live just as it can cease to be moved. However, the soul is a self-moving principle, a source and a beginning of movement, and what is begun must be uncreated, because if it were not uncreated, it would not have begun. Since it is uncreated, it is also indestructible, because if the soul, or the beginning of the movement, were destroyed, the whole universe and creation would collapse and become motionless. And the principle is just something unborn .... For any body that receives its movement from the outside is an inanimate body; instead, one who receives it from within, is himself animated, and in this lies the nature of the soul" (Platon, 1986a, p.441). Also, in the notes to 
the Phaidros Dialogue, Gabriel Liiceanu says about Socrates' reply: "I have, what is true, the gift of seeing with the spirit", that it would mean "I am a person endowed with the gift of divinati" (Platon, 1986a, p.504).

Plato continues in the dialogue of Phaidros, and through Socrates he exposes the way in which the immortal rational part contemplates the Being, describing the effect of this contemplation: to be touched, which can only contemplate the helm of the soul, the intellect, and which represents the object of true science - To The Being, therefore, is destined this place (superheaven) ..... the thought of any soul eager to receive what is right - it is natural that in time, when he looks at the being himself, he will feel joy and, in this contemplation of the truth, find his food and contentment. The soul remembers the ideas with which it came into contact while in the company of the gods, and after going through cycles of reincarnation for thousands of years, and lives lived in truth, it has the opportunity to regain its wings "in what the third millennial rotation, these souls, if they have chosen such a face of life three times in a row, regain their wings and, in the last of the three thousand years, go from here" (Platon, 1986a, p.444). The philosopher has a special place in the hierarchy of Plato's incarnations, his life lived in truth, being a guarantee of regaining his wings back.

Lifelong knowledge of the ideals of good, beauty, virtue, justice is done through the divine rational element, "which has a natural affinity with the invisible world, which it has the capacity to contemplate, while other elements of the soul are in a way essentially related to the body ... and does not participate directly in reason and rational activity. This dualistic conception reappears in Neoplatonism, and the theme of inner conflict in man is clear in the minds of those who support Christian morality" (Copleston, 2008, p.190).

Plato has dedicated his life to the search for truth. "Mastered by a living moral honesty ... he appealed to the care that men must take of their best value, which is the immortal soul, and to aiming at cultivating true virtues, the only ones that can bring happiness" (Copleston, 2008, p.233). Man reproduces at the microcosmic level, in his forum or interior, the movement of principles at the macrocosmic level, creating a connection with the divinity, a connection that passes over time through reincarnation.

\section{Mention of consciousness in late Stoicism. Self-concern and self- awareness}

If we are to look for a precise reference to the term selfconsciousness in ancient times, the closest to its definition were the Stoics. 
Somehow, they systematized in a more complete and structured process than all their predecessors, the journey of self-defining.

The founder of the Stoic philosophical school is Zeno of Kition, and we can distinguish several stages in the evolution and development of the school: early Stoicism, Middle Stoicism and the last phase of the school, Roman neo-Stoicism, illustrated by Seneca, Epictetus, Marcus Aurelius (Epictet, Marcus Aurelius. Manualul, Cätre Sine, 1977).

Stoic philosophy is organized in a system of three doctrines: logic, ethics and physics. In this school there is a strong preoccupation with identifying and transforming the self-knowing self, the other and reality, the problem of the criterion of truth, and in their cosmology they defined two principles of reality, one passive material and one active - the intellect or divinity. "Given that the highest manifestation of nature, man, is endowed with consciousness, we cannot assume that the whole of nature is unconscious, because the whole cannot be more imperfect than the part. Therefore, God is the conscience of the world." (Copleston, 2008, p.347). He forms the world, to later dissolve it into himself, repeating the process in an endless series of creations and destructions, including the soul returning to this great soul of the world.

The Stoics admit the existence of the Logos who orders the world and creates a theory of knowledge - human consciousness can know the world of objects due to the reason that organizes and controls the perceptual phenomena and representations. The ideal of the Stoics, the sage, or sophos, goes through a difficult process of self-transformation by cultivating a lifestyle dedicated to seeking peace of mind, self-attention and living in harmony with Nature and the Universe through the right action, a process completed by changing vision on life, one's own person and the perception of the universe.

The late Stoicism of the first period of the Roman Empire focuses especially on moral and ethical principles, emphasizing man's duty to love his neighbor. Seneca, professor of Emperor Nero, states "the materiality of the soul, but speaks in a Platonic manner about the conflict between soul and body, between the aspirations of the higher man and the doctrines of the flesh. True virtue and true value are inner: outer goods cannot generate true happiness, for they are fleeting gifts of fate, and we would be mad to trust them" (Copleston, 2008, p.385). Seneca was an active practitioner of the advice given, pursuing moral progress, regardless of where the struggle with the self takes place, valuing the forgiveness of others (Seneca, 1967). 


\subsection{Epictet. The Manual}

Epictetus of Hieropolis, also has a connection with Nero, being the freed slave of a soldier in the emperor's personal guard. He remains true to the traditional Stoic doctrine, stating that all people have the potential for virtuosity and are endowed with divinity with the ability to become happy. His perspective on the human being is that he exists in a reality with two aspects, one related to man and another independent of him: "There are among the realities that stand before us, some in our power and others independent of our will and power. We have the opinion, the impulses, the desire, the aversion, in a word, everything that represents our own activity. It is outside our will the body, the fame, the strength of a leader, in a word, everything that does not constitute specific tasks for us" (Epictet, Marcus Aurelius. Manualul, Către Sine, 1977, p.5). Consequently, well understood, they properly regulate our actions. People's education consists mainly of two factors, to live in harmony with nature and to distinguish between things that belong to their will and those that are not in their power. "Selfeducation consists in attaining true judgment and righteous will." (Copleston, 2008, p.387).

Epictetus proposes practical exercises to obtain a moral conduct progressively adjusted to the stated ideals: exercises of daily examination of consciousness, the development of an inner voice, like an observer who remembers what is possible and real in human power. A set of instructions for obtaining aversion and emotional detachment, the recommendation to make anticipatory representations of actions - as a mental simulation to prevent the generation of unrealistic expectations. The goal is to maintain a state of agreement with Nature, because "people are disturbed not by the things themselves but by the opinions they make about things." (Exictet, Marcus Aurelius. Manualul, Către Sine, 1977, p.9). For example, it is not death, but opinions about death that disturb us, just as it is not a person that makes us angry, but our opinion angers us. If man controls the formation of imaginations, the images that form the material basis of man's thoughts, then he shows power over himself and obtains detachment.

Interesting is his observation that, "disease is an obstacle to the body, not to thinking, if the thinking itself does not want to. Lameness is an obstacle for the foot, not for thinking" (Epictet, Marcus Aurelius. Manualul, Către Sine, 1977, p.10), because the power of the will goes to educate the body to finally follow the mind.

Copleston summarizes three stages in this moral progress. The first stage is the discipline of desires, aligning them with the right reason, the 
second is the transposition of debt into deeds and the third is related to judgment and consent.

\subsection{Marcus Aurelius. To himself}

Marcus Aurelius is one of the most important emperors and by the fact that he had a discipline of the intimate diary of philosophical reflection, with the recommendation of an organized life, in a gentle and modest language, with the perpetual examination of conscience and self-correction efforts. It promotes forgiveness and mercy, the duty of love of those around us.

"I am made up of an insignificant body and a soul. On the one hand, therefore, the body is all indifferent because it is not even able to distinguish them from each other, and thinking is indifferent to all activities that are not its own. On the other hand, the activities that are hers are all in her power." (Epictet, Marcus Aurelius. Manualul, Către Sine, 1977, p.144). Thought and soul are considered the most important, and contemplation is a source of personal power in the life of the individual.

Self-concern is a process that can be delimited in three dimensions: self-concern in relation to oneself, in relation to the other and in relation to the Universe or Nature. In the first case, it is important to discover the identity, not in relation to the physical body but from the perspective of the soul - the Hegemon is the one who has the power to choose, and makes visible the power and freedom of judgment of the Self. Self-awareness is transformed in relation to the physical and physical objects of the surrounding reality, "When a work can be completed, according to reason, common to gods and people, then there is nothing to fear. For, indeed, when it is possible to perform a useful action, developed in a just way, according to the nature of man, then no damage can be presumed" (Epictet, Marcus Aurelius. Manualul, Către Sine, 1977, p.162).

In the second case, the self-concern in relation to the other, is fulfilled by recommendations to take actions in the social interest, "Did I accomplish something in the interest of the society? So I did myself a favor! " because "The characteristic feature in the composition of man is sociability, and the second, relentless resistance to bodily passions .... The third feature of a rational constitution is the ability to reflect and the inability to deceive." (Epictet, Marcus Aurelius. Manualul, Către Sine, 1977, p.163). It considers the good of the nation and the action in the spirit of justice, or rather, the right action from a moral point of view.

At the third level is the self-concern in relation to the Universe, here speaking of a metaphysical perspective on the world as, for example, in the 
fragment: "All are intertwined with each other, their chain is holy and almost none is foreign or independent of the other. For they are all arranged together and complete the order of the same universe." (Epictet, Marcus Aurelius. Manualul, Către Sine, 1977, p.154). The Sage positions himself in the observer position, contemplates himself in the world and sees his belonging to the world being, at the same time detached from the body and its desires or needs. It also includes the contemplation of death and the eternal transformation of the elements from one to the other, because "those who come from the earth are scattered again in the earth, and those who sprout from the fruitful bosom of the air, return again to the heavenly vault." (Epictet, Marcus Aurelius. Manualul, Către Sine, 1977, p.162). Self-concern ends with finding the true self, the Hegemon, the driving force, his soul.

\section{Conclusions}

Analyzing the red thread of the construction of self-awareness, we can see an evolutionary process, with areas of transparency and different density, with the most consistent moment in the Stoic period. Societal transformations have mediated and enhanced this evolutionary process of thought and identity as a whole of ancient man. We can take as a lesson of antiquity the fertile and curious speculative thinking, the philosophy transformed into a lifestyle, the scientific pragmatism at its beginnings, the confidence in evolution and overcoming the mortal human condition, the concern for the immortal, rational, divine part as a treasure of humanity in us. The ancient thinker handed over the baton to Neoplatonism and Christian thought that continued to cultivate and value peace of mind, to promote an ascetic lifestyle that eliminates pleasures, self-concern in the sense of knowing the truth by faith. Self-awareness is preparing for a new step, with the development of Christianity and the promotion of its values. Thinking is practiced through introspection, managing the emotions associated with thoughts, practicing the reflective bending of the mind in the position of observer of destiny and death, conscious choices in accordance with the laws of the universe.

\section{References}

Banu, I. (1979). Filosofia greacă până la Platon, Vol. I, partea a II-a. Editura Științifică și Enciclopedică.

Bosman, P. (2003). Conscience in Philo \& Paul: A Conceptual History of the Synoida Word Group. Tübingen, Coronet Books.

Copleston, F. (2008). Istoria Filosofiei. Grecia și Roma, Vol. 1. Bucureşti, Editura All. 
Diels, H., \& Kranz, W. (1974). Fragmentele presocraticilor. Junimea.

Drăgănescu, M. (2000). Conştiința, frontieră a ştiinței şi frontieră a omenirii. Revista de filozofie, XLVII(1-2).

Epictet, Marcus Aurelius. Manualul, Către Sine (1977). Translated by D. Burtea \& M. Peucescu. Editura Minerva - Biblioteca pentru toți.

Frunză, A. (2016). Către o noua expertiză etică - deconstruind valorile etice. Editura LUMEN.

Pirie, M. (2011). 101 Mari filosofi. Creatorii gandirii modern. Orizonturi.

Platon, (1986a). Opere IV. Editura științifică și enciclopedică.

Platon, (1986b). Opere $V$. Editura științifică și enciclopedică.

Seneca, (1967). Scrisori către Luciliu. Translated by Gheorghe Guțu. Editura Stiintifică şi Enciclopedică.

Zeman, A. (2000). Consciousness in Action. Brain, 123(1), 87-189.

Zeman, A. (2001). Consciousness. Brain, 124(Pt 7), 1263-1289. 